\title{
The Peculiarities of Capital Investment in the Baltic States
}

\author{
Lina Sinevičienè, Kaunas University of Technology
}

\begin{abstract}
The paper presents the results from the research on capital investment changes in the context of economic development in the Baltic States. Statistical data analysis and cross-correlation analysis were used. The research showed that the volatility of real GDP growth and real investment growth was very high in the Baltic States compared with the EU countries average during the period of $2000-2011$. Higher investment growth provides a higher economic growth, but it may be associated with higher volatility of investment and economic growth. The share of government investment was high in the Baltic States compared with the EU countries average, but the government investment did not have stabilizing impact on the economy because of the procyclical manner and high volatility.
\end{abstract}

Keywords - Capital investment, economic development, the Baltic States.

\section{INTRODUCTION}

Scientific problem and novelty of the paper. The level of country's competitiveness and development, as well as the country's economic growth, depends on the growth of investment, thus, private and government investment plays an important role in the economy of each country at macroeconomic and microeconomic level [18]; and there is consensus regarding this issue in the scientific literature. In most cases, there is a strong relationship between the economic growth and the investment growth. According to [19], the GDP indicator has a positive relationship with private investment in the Baltic States and it is one of the key indicators of macroeconomic environment determining private investment behaviour. In this context, a more actual question is associated with investment volatility, its sources, and how investment volatility is related to economic growth and vice versa. So it is very important to assess peculiarities of how the components of investment change when country's economic growth changes, and which component of the investment is most volatile. Thus, the novelty of this paper is the analysis of the investment and changes of its structure in the context of economic development in the Baltic States - Estonia, Latvia, and Lithuania, during the period of $2000-2011$.

The research aim: to estimate the changes of capital investment growth in the Baltic States and to assess the relationship between the changes of capital investment growth and the GDP growth.

The research object: Capital investment in the Baltic States.

The research methods: Analysis and synthesis of scientific literature, logic analysis and synthesis, analysis of statistical data, cross-correlation analysis.

\section{Changes OF THE CAPITAL INVESTMENT IN THE CONTEXT OF ECONOMIC DEVELOPMENT}

Scientists agree that investment is an important factor for each country's economy; and it is one of the most important components of GDP. According to [9], investment has a substantial impact on the economic growth. If a country's investment ratio is only $5 \%-10 \%$ of the country's GDP, it is unlikely that the country's economic growth rate would be high for a long period of time. Strong, sustainable economic growth requires high investment rate. The country's overall investment ratio should be $25 \%$ of GDP and higher if the country seeks persistent and high economic growth [3].

After summarization of scientific literature, it can be stated that the investment growth is significant for each economy at macroeconomic and microeconomic level because:

1) changes of investment growth can have long-term consequences for the productive capacity of the economy and long-term economic growth [11], [12], [17], [16], [23], [26].

2) investment is one of the most important factors affecting the company's financial position, business continuity, development and competitiveness [22].

According to [17], investment is the most volatile component of GDP, so aggregate supply and demand is very sensitive to changes in investment and vice versa. Therefore it is very important to ascertain the sources of the capital investment volatility and to evaluate the relationship between the changes of various components of investment growth and GDP growth.

[18] - [19] present the review of various investment theories in order to determine the factors influencing the change of the capital investment. The following key factors, influencing capital investment, are: the level of output, financial resources and financing method of investment, the cost of capital, the level of capacity utilization, factors prices, and Tobin $\mathrm{Q}$ ratio. However, according to option theory, the main determinant of the investment is the uncertainty associated with these factors, such as uncertainty related to the macroeconomic environment, factors prices, stability and reliability of government policy. According to [19], all these factors considered in investment theories are the basis of empirical research, when determinants of capital investment are assessed.

In recent years, considerable attention is paid to government policy and its impact on capital investment. Government investment depends on the pursued fiscal policy and may have negative relationship with economic growth and private investment if the government's fiscal policy is countercyclical. There is consensus in the scientific literature that the government investment has productive capacity if it is not 
financed through rising public debt. But according to the option theory, private investment may be very sensitive to uncertainty of macroeconomic environment and can be delayed if the economy slows down, and especially if the government's fiscal policy is procyclical.

The relationship between the government and private investment is another important issue. Scientific literature contains indications that government investment can crowd in [1], [8], [10], [11] or crowd out private investment [13], [14]. It was established that changes of government investment can explain about $80 \%$ of private investment fluctuations in the Baltic States [19]. But the interrelation between the private and government investment is still unclear, it is still unclear, whether the government investment determines private investment or the private investment leads the government investment.

\section{RESEARCH METHODOLOGY AND DATA}

Investment can be classified in different ways. [22] provides a detailed classification of investment by various criteria; various types of investment are defined in [15], [24]. In this paper, investment is analyzed taking into account the investor's status, i.e., business investment, households' investment, and government investment.

Data. Empirical analysis focuses on the data for Estonia, Latvia, Lithuania and the European Union (EU) (27 countries average). Indicators are collected from Eurostat Statistics [6] (structure of capital investment) and Annual Macroeconomic Database of the European Commission [7] (capital investment components and GDP at 2005 market prices) databases. The study covers the period from 2000 to 2011 using annual data.

Stages of the empirical analysis:

Stage 1. The assessment of the investment growth and structure in the Baltic States.

In order to evaluate changes of capital investment and GDP, real growth rates of capital investment components and GDP were calculated at 2005 market prices.

In order to assess the average growth of investment and GDP in the Baltic States and in the EU (27 countries) a sample during 2000 - 2011, geometric average was calculated.

Standard deviation was calculated in order to assess volatility of investment and GDP growth in the Baltic States during 2000 2011.

In order to assess the investment structure, the shares of business investment, government investment, and households' investment in total investment were calculated.

Stage 2. The assessment of the relationship between the capital investment and GDP growth in the Baltic States.

In order to assess the relationship between the capital investment growth and GDP growth in different time lags, cross-correlation was calculated.

Time series have to be stationary when cross-correlation procedure is used. The most effective way to make a drifting series stationary is to differentiate it. Taking differences simply means replacing the original series by the differences between adjacent values in the original series [21].
According to [25], given two time series, $x_{t}$ and $y_{t}$, for data pairs $\left(x_{1}, y_{1}\right),\left(x_{2}, y_{2}\right),\left(x_{n}, y_{n}\right)$ an estimate of lag $k$ cross covariance is calculated as follows:

$$
c_{x y}(k)= \begin{cases}\frac{1}{n} \sum_{i=1}^{n-k}\left(x_{i}-\bar{x}\right)\left(y_{i+k}-\bar{y}\right), \quad k=0,1,2 \ldots \\ \frac{1}{n} \sum_{i=1}^{n-k}\left(y_{i}-\bar{y}\right)\left(x_{i-k}-\bar{x}\right), \quad k=0,-1,-2 \ldots\end{cases}
$$

where $x$ and $y$ are sample means of the time series $x_{t}$ and $y_{t}$.

The estimate of the cross correlation function between two time series $x_{t}$ and $y_{t}$ is expressed as:

$$
r_{x y}(k)=\frac{c_{x y}(k)}{s_{x} s_{y}}, k=0, \pm 1, \pm 2 \ldots
$$

where $s_{x}=\sqrt{c_{x x}(0)}, s_{y}=\sqrt{c_{y y}(0)}$ are sample standard

deviations of the time series $x_{t}$ and $y_{t}$ [25].

Cross-correlations were calculated using SPSS Statistics 17.0 software package.

\section{INVESTMENT GROWTH AND STRUCTURE IN THE BALTIC STATES}

The statistical data of averaged real GDP and real investment growth rates showed that GDP, households' investment, business investment, and total investment fluctuation was very similar in the case of the EU (27 countries) sample (Table I).

Government investment was very volatile in the EU (27 countries average), but, on average, it even grew in 2008 - 2010. Government investment growth was negative in 2010 - 2011, but its decline was less than other investment components during the financial crisis. This phenomenon can be explained by the fact that many governments could not increase investment due to the increased government budget deficits as a consequence of the financial crisis.

Government investment fluctuated significantly more than GDP in Estonia. Government investment began to rise after one year when Estonian economy began to recover in 2010. The data showed that the government investment was very procyclical in Estonia from 2004 to 2009.

The situation in Latvia was very similar to the Estonian. Government investment and households' investment was the source of total investment growth from 2002 to 2005. After this period its growth rate slowed down as the GDP growth slowed down. The boom of households' investment was observed in 2005, households' investment growth was more than $200 \%$ in this year in Latvia.

The main source of total investment growth was households' investment in Estonia and Latvia. In Lithuania, the government investment growth was the main source of total investment growth until 2007. Business investment was the most stable component of total investment until 2008 and had large influence on total investment growth, but the decline of business investment was the highest compared with other investment components' decline during the financial crisis in Lithuania. 
TABLE I

GROWTH OF INVESTMENT AND GDP IN THE EUROPEAN UNION (27 COUNTRIES), ESTONIA, LATVIA, AND LiTHUANIA (\%)

\begin{tabular}{|c|c|c|c|c|c|c|c|c|c|c|c|c|}
\hline Indicator & 2000 & 2001 & 2002 & 2003 & 2004 & 2005 & 2006 & 2007 & 2008 & 2009 & 2010 & 2011 \\
\hline & \multicolumn{12}{|c|}{ EU (27 countries) } \\
\hline Total investment & 4.5 & 0.8 & -0.6 & 1.1 & 3.0 & 3.5 & 6.3 & 6.3 & -1.1 & -13.0 & 0.0 & 1.4 \\
\hline Households' investment & 3.1 & 0.7 & 2.5 & 4.6 & 5.2 & 3.4 & 6.2 & 4.9 & -7.7 & $\begin{array}{ll}-14.8 \\
\end{array}$ & 0.9 & 0.5 \\
\hline Government investment & 1.4 & 6.3 & -0.1 & 7.5 & 0.9 & -4.9 & 12.7 & 8.4 & 5.3 & 3.4 & -4.9 & -7.1 \\
\hline Business investment & 5.7 & -0.2 & -2.3 & -2.0 & 2.3 & 5.4 & 5.1 & 6.6 & 1.2 & -15.9 & 1.0 & 4.2 \\
\hline \multirow[t]{2}{*}{ GDP growth } & 3.9 & 2.1 & 1.3 & 1.5 & 2.5 & 2.1 & 3.3 & 3.2 & 0.3 & -4.3 & 2.1 & 1.6 \\
\hline & \multicolumn{12}{|c|}{ Estonia } \\
\hline Total investment & & 13.1 & 24.2 & 16.7 & 6.0 & 15.2 & 23.0 & 9.3 & -13.3 & -38.3 & -7.4 & 25.7 \\
\hline Households' investment & & 25.3 & 26.0 & 26.7 & 23.0 & 37.8 & 48.4 & 1.1 & -32.8 & -31.1 & 0.4 & 22.0 \\
\hline Government investment & & 20.9 & 43.3 & -9.7 & -5.8 & 15.9 & 29.5 & 19.7 & 8.2 & -16.8 & -21.7 & 20.0 \\
\hline Business investment & & 9.5 & 19.6 & 21.7 & 4.7 & 9.6 & 13.7 & 10.5 & -11.0 & -46.3 & -4.1 & 29.1 \\
\hline \multirow[t]{2}{*}{ GDP growth } & & 6.3 & 6.6 & 7.8 & 6.3 & 8.9 & 10.1 & 7.5 & -4.2 & -14.1 & 3.3 & 8.3 \\
\hline & \multicolumn{12}{|l|}{ Latvia } \\
\hline Total investment & 10.1 & 11.4 & 12.9 & 12.3 & 23.7 & 23.5 & 16.3 & 7.9 & -13.8 & -37.4 & -18.1 & 27.9 \\
\hline Households' investment & -3.6 & 9.6 & 12.7 & 9.5 & 53.7 & 205.8 & 5.7 & 6.8 & 3.2 & -39.0 & -43.6 & 34.6 \\
\hline Government investment & -4.8 & -9.7 & 34.9 & 105.2 & 43.8 & 10.3 & 63.0 & 28.3 & -15.4 & -24.0 & -15.9 & 23.9 \\
\hline Business investment & 12.0 & 12.8 & 11.9 & 7.0 & 19.6 & 11.3 & 12.2 & 4.1 & -16.8 & -40.3 & -12.2 & 28.0 \\
\hline \multirow[t]{2}{*}{ GDP growth } & 5.7 & 7.3 & 7.2 & 7.6 & 8.9 & 10.1 & 11.2 & 9.6 & -3.3 & -17.7 & -0.9 & 5.5 \\
\hline & \multicolumn{12}{|c|}{ Lithuania } \\
\hline Total investment & -8.4 & 13.2 & 10.7 & 13.5 & 15.7 & 11.2 & 19.3 & 21.8 & -5.2 & -39.5 & 1.9 & 18.3 \\
\hline Households' investment & 13.0 & 9.6 & 3.2 & 28.4 & 13.8 & 0.3 & -2.0 & 13.0 & 10.3 & -18.5 & -32.7 & 6.0 \\
\hline Government investment & -1.0 & -1.4 & 41.6 & 13.4 & 27.2 & 8.8 & 29.5 & 36.4 & -0.2 & -29.6 & 25.8 & 4.4 \\
\hline Business investment & -14.2 & 16.9 & 7.8 & 9.8 & 13.9 & 14.9 & 22.5 & 20.1 & -9.5 & -47.5 & 5.1 & 28.1 \\
\hline GDP growth & 3.6 & 6.7 & 6.8 & 10.3 & 7.4 & 7.8 & 7.8 & 9.8 & 2.9 & -14.8 & 1.5 & 5.9 \\
\hline
\end{tabular}

TABLE II

VOLATILITY AND GROWTH OF INVESTMENT AND GDP IN THE BALTIC STATES

\begin{tabular}{|l|l|l|l|l|c|l|l|l|}
\hline Country & \multicolumn{2}{|l|}{ EU (27 countries) } & \multicolumn{2}{l|}{ Estonia } & \multicolumn{2}{l|}{ Latvia } & \multicolumn{2}{l|}{ Lithuania } \\
\hline Indicator & $\begin{array}{l}\text { Geometric } \\
\text { average, \% }\end{array}$ & $\begin{array}{l}\text { Standard } \\
\text { deviation }\end{array}$ & $\begin{array}{l}\text { Geometric } \\
\text { average, \% }\end{array}$ & $\begin{array}{l}\text { Standard } \\
\text { deviation }\end{array}$ & $\begin{array}{l}\text { Geometric } \\
\text { average, \% }\end{array}$ & $\begin{array}{l}\text { Standard } \\
\text { deviation }\end{array}$ & $\begin{array}{l}\text { Geometric } \\
\text { average, \% }\end{array}$ & $\begin{array}{l}\text { Standard } \\
\text { deviation }\end{array}$ \\
\hline Total investment & 0.9 & 5.1 & 4.8 & 19.4 & 4.4 & 19.5 & 4.4 & 17.2 \\
\hline Households' investment & 0.6 & 6.1 & 10.1 & 26.3 & 10.5 & 63.9 & 2.4 & 16.0 \\
\hline Government investment & 2.2 & 6.0 & 7.6 & 20.5 & 14.9 & 38.2 & 11.1 & 20.2 \\
\hline Business investment & 0.7 & 6.1 & 2.8 & 20.5 & 2.3 & 18.6 & 3.2 & 20.8 \\
\hline GDP growth & 1.6 & 2.1 & 4.0 & 7.2 & 3.9 & 8.2 & 4.4 & 6.7 \\
\hline
\end{tabular}

The data presented in Table I show that the investment growth and GDP growth were very sensitive to the financial crisis in the Baltic States. The decline of the investment and GDP began in 2008 and lasted nearly three years. Whereas, aftermath of the crisis was smaller; and it lasted shorter in the case of the EU countries' sample (on average).

The statistical analysis of the data showed that GDP growth rate and total investment growth rate were very similar in all three countries, but significantly higher than the average of the EU (27 countries) (Table II).

The lowest real growth of investment (about $4.4 \%$ ) was in Lithuania and Latvia during the period of $2000-2011$. The volatility of real GDP growth and real investment growth was the lowest in the case of Lithuania (the lowest standard deviation of GDP growth and investment growth was observed) compared with Estonia and Latvia during the period of 2000 - 2011. Business investment was one of the most stable components of the investment in Estonia and Latvia. The main source of total investment volatility was the volatility of households' investment (except in Lithuania), and the volatility of government investment. High volatility of government investment showed that fiscal policy was not stable in the Baltic States. Uncertainty and volatility of macroeconomic environment can be harmful for the investment growth [5], so volatile fiscal policy can be harmful for the investment growth too. 
TABLE III

THE STRUCTURE OF INVESTMENT IN THE BALTIC STATES

\begin{tabular}{|l|l|l|l|l|}
\hline \multicolumn{1}{|c|}{ Indicator } & EU (27 countries) & \multicolumn{1}{c|}{ Estonia } & \multicolumn{1}{c|}{ Latvia } & Lithuania \\
\hline Total investment, \% of GDP & 19.9 & 28.5 & 26.3 & 21.4 \\
\hline Households investment, \% of total investment & 30.5 & 18.5 & 10.7 & 16.8 \\
\hline Government investment, \% of total investment & 12.5 & 16.2 & 12.8 & 76.5 \\
\hline Business investment, \% of total investment & 57.0 & 65.3 & 87.2 & 65.5 \\
\hline Private investment, \% of total investment & 87.5 & 83.8 & 82.3 \\
\hline
\end{tabular}

The main determinant of country's investment level and growth, especially the level of private investment, is GDP growth (or output growth) [2], [4], [20]. The research showed that fluctuations of GDP growth and investment growth were very similar in all three Baltic States. The changes of credit conditions and interest rates were very important factors of the identified investment changes. The changes of government investment depend on the fiscal policy pursued by the government. Government should pursue countercyclical fiscal policy in order to stabilize economy, but changes of the government investment were procyclical in the Baltic States during the period of $2000-2011$.

The analysis of the investment structure showed that the structure of investment in the Baltic States differed from the structure of the EU countries average during 2000-2011 (Table III).

The research showed that the investment ratio to GDP was the highest in Estonia: on average $28.5 \%$ of GDP, while in Lithuania - only $21.4 \%$ of GDP; and average of the EU was only $19.9 \%$ of GDP. The share of households' investment was significantly lower in the Baltic States compared with the average of the EU countries. This fact explained why the share of business investment in total investment structure was higher in the Baltic States compared with the EU average.

The share of private investment (households' investment plus business investment) in investment structure was about $3 \%-5 \%$ points lower in Estonia and Lithuania than in the EU (27 countries) and Latvia. This showed that the government investment was relatively high in Estonia and Lithuania. According to the classical economic theory, large government sector may be harmful for the economic growth and the government investment can crowd out the private investment. Therefore the impact of higher level of government investment on private investment may be negative.

The structure of investment by type of goods was very similar in all three countries therefore the detailed results of this analysis were not represented in this paper.

\section{RELATIONSHIP BETWEEN CAPITAL INVESTMENT AND GDP GROWTH IN THE BALTIC STATES}

Cross-correlations were evaluated (Table IV) in order to better assess the relationship between different investment components and GDP growth. Time series were differentiated at degree 1 in order to make time series stationary.

Very strong positive correlations (strong in case of Lithuania) between GDP and total investment growth and between GDP and business investment growth were found in 0 lag in the analysed countries. Strong correlation between households' investment and GDP growth was found in the EU and Estonia in 0 lag. Moderate correlation between households' investment and GDP growth was found in Lithuania in -1 lag, this means that GDP increases first, and then after 1 year increases the households' investment. The positive correlation between government investment and GDP growth in 0 lag showed that the government investment tended to be procyclical in the Baltic States.

According to economic theory, it is very important to assess whether the government investment crowds in or crowds out private investment. The research showed that negative relationship between households' investment and government investment, business investment and government investment was most often observed in the EU (27 countries). Government investment tended to be the leading indicator in this case.

There was no clear evidence of which indicator was leading, but there was positive relationship between government investment and households' investment, government investment and business investment in 0 lag in the case of Estonia. In the case of Latvia, there was negative relationship between households' investment and government investment in 0 lag. Positive relationship existed between government investment and business investment in lag 1 , and government investment was the leading indicator in this case. There was strong positive relationship between households' investment and government investment in -1 lag in the case of Lithuania. This means that government investment was the leading indicator. 
TABLE IV

CROSS-CORRELATIONS BETWEEN INVESTMENT GROWTH AND GDP GROWTH

\begin{tabular}{|c|c|c|c|c|c|c|c|}
\hline Lag & $\begin{array}{l}\text { Total investment } \\
\text { with GDP } \\
\text { growth }\end{array}$ & $\begin{array}{l}\text { Households' } \\
\text { investment with } \\
\text { GDP growth }\end{array}$ & $\begin{array}{l}\text { Government } \\
\text { investment with } \\
\text { GDP growth }\end{array}$ & $\begin{array}{l}\text { Business } \\
\text { investment with } \\
\text { GDP growth }\end{array}$ & $\begin{array}{l}\text { Households' } \\
\text { investment with } \\
\text { Government } \\
\text { investment }\end{array}$ & $\begin{array}{l}\text { Households' } \\
\text { investment with } \\
\text { Business } \\
\text { investment }\end{array}$ & $\begin{array}{l}\text { Government } \\
\text { investment with } \\
\text { Business } \\
\text { investment }\end{array}$ \\
\hline \multicolumn{8}{|c|}{ EU (27 countries) } \\
\hline-3 & -0.118 & -0.028 & 0.075 & -0.163 & -0.144 & -0.027 & 0.034 \\
\hline-2 & -0.317 & -0.319 & 0.169 & -0.317 & -0.469 & -0.166 & 0.143 \\
\hline-1 & -0.086 & -0.328 & 0.055 & 0.013 & 0.045 & -0.473 & 0.246 \\
\hline 0 & 0.979 & 0.922 & -0.093 & 0.936 & -0.051 & 0.798 & -0.267 \\
\hline 1 & -0.253 & 0.050 & 0.073 & -0.397 & 0.034 & 0.302 & 0.078 \\
\hline 2 & -0.303 & -0.416 & -0.296 & -0.148 & 0.143 & -0.380 & -0.124 \\
\hline 3 & -0.070 & -0.061 & -0.326 & -0.004 & 0.123 & -0.179 & -0.556 \\
\hline \multicolumn{8}{|c|}{ Estonia } \\
\hline-3 & -0.345 & -0.194 & -0.257 & -0.332 & -0.288 & 0.047 & -0.118 \\
\hline-2 & -0.447 & -0.433 & -0.169 & -0.427 & -0.554 & -0.396 & -0.277 \\
\hline-1 & 0.404 & 0.043 & 0.552 & 0.360 & -0.127 & -0.102 & 0.292 \\
\hline 0 & 0.869 & 0.700 & 0.274 & 0.912 & 0.340 & 0.602 & 0.445 \\
\hline 1 & 0.064 & 0.610 & -0.061 & -0.111 & 0.455 & 0.662 & 0.085 \\
\hline 2 & -0.359 & -0.154 & -0.303 & -0.350 & 0.192 & 0.020 & -0.327 \\
\hline 3 & -0.326 & -0.718 & -0.324 & -0.110 & -0.265 & -0.722 & -0.320 \\
\hline \multicolumn{8}{|c|}{ Latvia } \\
\hline-3 & -0.402 & -0.144 & -0.185 & -0.363 & -0.341 & -0.037 & -0.122 \\
\hline-2 & -0.543 & -0.157 & -0.141 & -0.567 & 0.685 & -0.276 & 0.041 \\
\hline-1 & 0.510 & 0.266 & 0.209 & 0.371 & 0.082 & 0.407 & 0.106 \\
\hline 0 & 0.775 & 0.159 & 0.292 & 0.841 & -0.400 & 0.193 & 0.277 \\
\hline 1 & 0.108 & -0.024 & 0.243 & 0.119 & 0.373 & 0.004 & 0.304 \\
\hline 2 & -0.176 & 0.285 & -0.224 & -0.232 & 0.136 & 0.073 & -0.191 \\
\hline 3 & -0.114 & 0.123 & -0.263 & -0.123 & -0.195 & 0.071 & -0.373 \\
\hline \multicolumn{8}{|c|}{ Lithuania } \\
\hline-3 & -0.006 & -0.241 & 0.133 & -0.007 & -0.393 & -0.304 & 0.122 \\
\hline-2 & -0.362 & -0.381 & -0.098 & -0.370 & -0.243 & -0.031 & -0.229 \\
\hline-1 & -0.148 & 0.647 & -0.381 & -0.167 & 0.878 & 0.601 & -0.084 \\
\hline 0 & 0.929 & 0.376 & 0.577 & 0.903 & -0.257 & 0.243 & 0.548 \\
\hline 1 & 0.050 & -0.424 & 0.251 & 0.065 & -0.231 & -0.400 & 0.079 \\
\hline 2 & -0.348 & -0.263 & -0.459 & -0.237 & -0.126 & -0.255 & -0.390 \\
\hline 3 & -0.135 & 0.211 & -0.093 & -0.176 & 0.322 & 0.282 & -0.117 \\
\hline
\end{tabular}

Note: The maximum strength of correlation is marked in gray

From the cross-correlation analysis there was no clear evidence if the government investment crowded in private investment in the Baltic States. But it could be concluded that there was high dependence between the business investment and the GDP growth, whereas households' investment in relation to GDP growth was lower.

\section{CONCLUSION}

1. The research showed that real GDP growth rate was very similar in all three Baltic States but significantly higher than the average of the EU (27 countries). The lowest real growth of investment was in Lithuania and Latvia (about $4.4 \%$ ) during the period of $2000-2011$. The volatility of real GDP growth and real investment growth was the lowest in Lithuania compared with Estonia and Latvia but significantly higher compared with the EU (27 countries average). The business investment was one of the most stable components of investment in Estonia and Latvia. The main source of total investment's volatility was households' investment (except in Lithuania), and government investment in Latvia. The high volatility of government investment showed that fiscal policy in the Baltic States was not stable.

2. The lowest investment to GDP ratio was in Lithuania compared with Estonia and Latvia but higher than the EU average during the period of $2000-2011$. The share of private investment in investment structure was about $3-5$ percentage points lower in Estonia and Lithuania than in the EU and Latvia. 
The research showed that government investment was relatively high in these countries. The share of government investment was high in the Baltic States compared with the EU countries' average, but government investment did not have stabilizing impact on the economy because of their procyclical manner and high volatility.

3. It can be concluded that there was strong relationship between business investment and GDP growth, while households' investment in relation to GDP growth was lower. There was no clear evidence from the cross-correlation analysis results if government investment crowded in private investment in the Baltic States. Further research is needed to assess this relationship.

4. The research results should draw the attention of the governments of the Baltic States to the high volatility of government investment in these countries, compared with the EU countries' average, because the fiscal policy should help to decrease volatility of country's investment and GDP but not to deepen the problem.

\section{REFERENCES}

[1] Ahmad, I. and Qayyum, A., "Effect of Government Spending and MacroEconomic Uncertainty on Private Investment in Services Sector: Evidence from Pakistan," in European Journal of Economics, Finance and Administrative Sciences, 2008, vol. 11, pp. 84-96.

[2] Ang, J. B., "Determinants of Private Investment in Malaysia: What Causes the Postcrisis Slumps?," in Contemporary Economic Policy, 2010, vol. 28, pp. 378-391. http://dx.doi.org/10.1111/j.1465-7287.2009.00155.x

[3] Commission on Growth and Development, "The Growth Report: Strategies for Sustained Growth and Inclusive Development," World Bank, 2008 [Online]. Available: http://www.ycsg.yale.edu/center/forms/ growthReport.pdf [Accessed: Feb. 15, 2013].

[4] De Mendonca, H. and Lima, T." "Macroeconomic Determinants of Investment under Inflation Targeting: Empirical Evidence from the Brazilian Economy," in Latin American Business Review, 2011, vol. 12 , no. 1, pp. 25-38. http://dx.doi.org/10.1080/10978526.2011.565697

[5] Demir, F., "Macroeconomic Uncertainty and Private Investment in Argentina, Mexico and Turkey," in Applied Economics Letters, 2009, vol. 16, no. 6, pp. 567-571. http://dx.doi.org/10.1080/13504850701206528

[6] European Commission, EUROSTAT database, 2013.

[7] European Commission, Annual Macroeconomic Database of the European Commission (AMECO), 2013.

[8] Gjini, A. and Kukeli, A., "Crowding-Out Effect of Public Investment on Private Investment: An Empirical Investigation," in Journal of Business \& Economics Research, 2012, vol. 10, no. 5, pp. 269-276.

[9] Hare, P. and Fofie, F. O., "Investment Behaviour in a Difficult Institutional Environment," Discussion Paper no. 46, 2010 [Online]. Available: http://www.ippg.org.uk/papers/dp46.pdf [Accessed Nov. 11, 2011].

[10] Hunt, C., "The Interaction of Public and Private Capital: a Study of 20 OECD Members," in Applied Economics, 2012, vol. 44, no. 6, pp. 739-764. http://dx.doi.org/10.1080/00036846.2010.522523

[11] Jongwanich, J. and Kohpaiboon, A., "Private Investment: Trends and Determinants in Thailand," World Development, 2008, vol. 36, no. 10, pp. 1709-1724. http://dx.doi.org/10.1016/j.worlddev.2008.01.010
[12] Karagöz, K., "Determining Factors of Private Investments: An Empirical Analysis for Turkey," in Sosyoekonomi, 2010, vol. 6, no. 1, pp. 7-25.

[13] Luintel, K. B. and Mavrotas, G., "Examining Private Investment Heterogeneity. Evidence from a Dynamic Panel", UNU-WIDER Discussion Paper No. 2005/11, 2005 [Online]. Available: wider.unu.edu [Accessed Sep. 10, 2012].

[14] Mehnatfar, U., "The Assessment of the Effect of Determinants of Private Investment in Iran: an Empirical Analysis (1971-2008)," in Australian Journal of Basic and Applied Sciences, 2010, vol. 4, no. 12, pp. 6292-6299.

[15] OECD, Glossary of statistical terms, 2013 [Online]. Available: http://stats.oecd.org/glossary/index.htm [Accessed Sep. 10, 2013].

[16] V. Pukelienė and A. Linkevičienè, "Mažų Ekonomikų Augimo Veiksniai: Atvirumo Poveikis Lietuvos Ekonominiam Augimui," Taikomoji ekonomika: sisteminiai tyrimai, 2008, vol. 2, no. 2, pp. 29-44.

[17] Samuel, Ch., "The Investment Decision: A Re-Examination of Competing Theories Using Panel Data". Policy Research Working Paper, no. 1656, 1996. The World Bank.

[18] Sinevičienè, L., "The Impact of Government's Fiscal Policy on Private Investment," Ph. D. dissertation, Kaunas University of Technology, Lithuania, 2013.

[19] Sinevičienè, L., "Kapitalo investicijas lemiantys veiksniai investiciju teoriju raidos kontekste," Ekonomika ir vadyba: aktualijos ir perspektyvos: mokslo darbai, 2013, vol. 4, no. 32, pp. 18-27.

[20] Sinevičienè, L. and Vasiliauskaite, A., "Fiscal Policy Interaction with Private Investment: the Case of the Baltic States," in Inzinerine Ekonomika-Engineering Economics, vol. 23, no. 3, 2012, pp. 233-241.

[21] SPSS Trends 10.0, SPSS Inc., United States of America, 1999 [Online]. Available: http://www.bf.lu.lv/grozs/Datorlietas/SPSS/SPSS\%20Trends\% 2010.0.pdf [Accessed: Nov. 10, 2013].

[22] Tomaševič, V. and Mackevičius, J., "Materialiujų Investicijų Analizè ir jų Itakos Vertinimas," Verslo ir teisés aktualijos, 2010, vol. 1, no. 5, pp. 186-203.

[23] Tvaronavičius, V. and Tvaronavičienė, M., "Role of Fixed Investments in Economic Growth of Country: Lithuania in European Context," in Journal of Business Economics and Management, 2008, vol. 9, no. 1, pp. 57-65.

[24] Valentinavičius, S. "Investicijų valdymas. Teoriniai ir praktiniai aspektai: monografija," Vilnius: Vilniaus universiteto leidykla, 2008, p. 304.

[25] Zalgiryte, L., Guzavicius, A. and Tamulis, V., "Stock Market and Economic Growth in the U.S. \& France: Evidence from Stock Market Sector Indices, “ in Inzinerine Ekonomika-Engineering Economics, 2014, vol. 25 , no. 1 , pp. 47-53.

[26] Zinkevičienė, D. and Bružauskas, V., "Kapitalo Investiciju Apskaitos Metodikos Ittaka Apskaitos Informacijos Kokybei," Management theory and studies for rural business and infrastructure development. Research papers, 2010, vol. 5, no. 24.

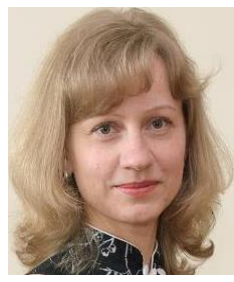

Lina Sinevičienė was born in Lithuania in June, 1977. She received the Doctoral degree in Social Sciences (Economics) from Kaunas University of Technology in 2013.

She is a Lecturer with the Department of Finance, School of Economics and Business, Kaunas University of Technology, Lithuania. She has worked as Chief Financial Officer in private enterprises. Her research interests are: capital investment, fiscal policy, fiscal policy interaction with private investment, public finance, financial system. Address: K. Donelaicio Str. 73, LT-44309 Kaunas, Lithuania.

E-mail: lina.sineviciene@ktu.lt 